\title{
Preliminary valuation of environmental importance of brazilian sites, with regards to ecological and sociocultural axes
}

\author{
Martha Isabel Mejía De Alba ${ }^{I}$ \\ Oscar Javier Obando Rodríguez II \\ Laura Patricia Osorio Osorio"II \\ Ivonne Dayana Vargas Pinilla IV
}

${ }^{1}$ Fundación Planeta Vivo Bta, Bogotá D.C., Colombia

II Fundación Planeta Vivo Btá, Bogotá D.C., Colombia.

D III Universidad Distrital Francisco José de Caldas, Bogotá D.C., Colombia.

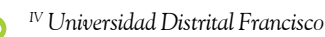
José de Caldas, Bogotá D.C., Colombia.

\begin{abstract}
The objective of this article is to prioritize sites of environmental importance in Brazil, according to their need for protection or conservation. For this, a methodology was applied in the sites that presented geographical overlap or proximity between protected areas and ethnic communities were selected to be evaluated taking into account criteria that define their ecological, social and cultural importance, such as: area of influence, integrated areas, anthropic pressure, species conservation status, Ramsar sites, hotspot, biosphere reserve, IBA and KBA sites, natural heritage, status of recognition and relationship between indigenous lands and quilombos, historical value, archaeological sites and cultural heritage. As a result, 1651 sites were identified, 249 were selected and evaluated, obtaining 14 with high, 91 medium and 144 low priority. With this information, the objective is to generate technical support that serves as an input for the generation of public policies aimed at its protection and conservation.
\end{abstract}

Keywords: Ecological and sociocultural valuation; sites of environmental importance in Brazil; environmental vulnerability in Brazil; brazilian environmental policy.

São Paulo. Vol. 24, 2021

Original Article

DOI: http://dx.doi.org/10.1590/1809-4422asoc20200209r1vu2021L5AO 


\section{Introduction}

Brazil is a fundamental country at the global context of sustainable development due to its already recognized and exuberant biodiversity and its great extension, being the holder of different biogeographic zones or different biomes: The Amazon, the largest tropical humid forest in the world; the Pantanal, the largest floodplain on the planet; the Cerrado, the second largest biome in South America; the Caatinga, with semi-arid forests; the fields of the Pampas; and the rainforest of the Atlantic Forest. (MINISTÉRIO DO MEIO AMBIENTE, 2020). These have housed and sustained a rich socio-biodiversity, represented in numerous indigenous communities and quilombos (ethnic groups made up of the black population descended from emancipated slaves and characterized by having their own cultural identity where their customs, organization and traditions widely distinguish them from other ethnic communities), who have made their territory the basis of the construction of their culture and which, in addition, according to the Environment Ministry (2018), are holders of very important knowledge on the conservation of biodiversity

In recent years, Brazil has positioned itself as one of the most important countries in the South American continent, in economic terms, because it has a wide range of products and services. Unfortunately, due to the neoliberal model that has been developing in the region, great social, cultural and ecological problems have been perceived, these problems are evident in the increase in inequality, unemployment and the over-exploitation of natural resources.

Attention to environmental problems and, [by extension, sociocultural], and the creation of policies have evolved from the beginnings of the so-called conservationists [...] to the consideration of sustained management of resources, first as eco-development and, later, as sustainable development, that is, from a strictly biological and ecological perspective to an environmental dimension in the society-nature relationship. (ZAMBRANO; GOYAS; SERRANO, 2018, p. 2).

The previous consideration requires initiating and monitoring public policies, these find a framework from the United Nations Conference for the Human Environment, in the city of Stockholm, in 1972.

Although it is true, the Stockholm Declaration is the starting point that shows the willingness of some countries to address a specific impact that had been monitored and that was causing damage to the environment and some populations; however, and although the Stockholm Convention was a great first step regarding the importance that the world gave to the environment and the planet's self-sustainability, its greatest achievement was opening the doors to a more in-depth discussion that revolved around globalization and addressed the need for nations to generate wealth to meet the basic needs of their growing population, in the face of the pressure that was being generated on the ecological base and natural resources, as established in the General Assembly of Nations United, which was held in Rio de Janeiro in 1992. 
This discussion was resumed two decades later, during the United Nations Conference on Sustainable Development, held in 2012 and was held in the same city. During that meeting, which was called "The Future We Want," two main issues were discussed: the first, aimed at building a green economy, which suggests that social well-being can be achieved while reducing environmental risks and ecological threats; the second aimed to improve international coordination in the pursuit of achieving this sustainable development.

With the development of the Rio 92 meeting, the "People's Summit" also appeared. This summit gave a lot of prominence to different political organizations and social movements, and also focused its attention on climate change and the threat to human survival. At this Summit, which was held for the first time in Mar del Plata in 2005, it was established that the climate crisis is a global problem that affects the entire population and whose impact is greater on those individuals, groups and peoples who are in a situation of vulnerability. In conclusion, the climate crisis affects countries unequally and its consequences are increased conflicts and political instability, as well as food inequality.

As indicated by Lima (2011, p.4, our translation), from this conference,

the process of institutionalization of environmental policies and management in Brazil experienced considerable progress, especially in institutional and legal aspects [...]; [Proof of this is the creation of different governmental environmental agencies]: Special Secretariat for the Environment (SEMA), in 1973; the Brazilian Institute for the Environment and Renewable Resources (IBAMA), in 1989; the MMA, in 1993; the National Water Agency (ANA), in 2001; the Chico Mendes Institute for Biodiversity Conservation (ICMBio), in 2007; among many others [...]. A broad legal apparatus was also built that includes the National Environmental Policy [...] and the National Environmental System (SISNAMA), in 1981; the National Water Resources Policy (PNRH), in 1997; [...] The National Environmental Education Policy (PNEA), in 1999; [and, among others], the National System of Conservation Units (SNUC), in the year 2000".

The latter, faces the importance of the territory as an element of planning, development and conservation.

It follows that the use of nature and, by extension, the use of the territory, constitutes the essence of regulatory intervention, [...] which is why it can be said that an environmental policy necessarily has a territorial dimension [...]. (STEINBERGER, 2013, p. 115, our translation). It should be noted that two instruments of environmental and territorial planning regulate the use of nature and the use of the territory, these are: ecological-economic zoning and conservation units. (STEINBERGER, 2013, p. 116, our translation).

Currently, the environment and its ecosystems are not only important issues due 
to its care and conservation, it has also become a topic of great interest considering its economic contribution. Food production, disease control, pharmaceutical product manufacturing and tourism are some of the ecosystem services that are discussed in events such as "the Ibero-American Summit of Heads of State and Government", an event in which, According to the report entitled "Latin America and the Caribbean: a superpower in biodiversity" a call is made to governments and a form of initiatives is urged to facilitate investment by the public and private sectors in ecosystem preservation projects. (PROGRAMA DE LAS NACIONES UNIDAS PARA EL DESARROLLO, 2013)

Today it is a need for all States to regulate and control the use of natu-
ral resources and the quality of the environment; in order to guarantee
environmental sustainability and quality of life, environmental public
policies are materialized, which integrate a set of principles, criteria
and general guidelines, strategically formulated, for their protection,
the improvement of environmental conditions and, in some cases,
specifically, they respond to priority environmental problems. (ZAM-
BRANO; GOYAS; SERRANO, 2018, p 4).

As mentioned above, in the formulation of public policies it is necessary to evaluate the economic contribution of biodiversity and ecosystem services. The concept of "socio-ecological system for environmental management" is proposed [...] "to create an ideal management unit to achieve sustainable development through public policies not exclusively predicated in the name of economic growth. (Gallopin et al., 1989; Gallopin, 1994, apud Challenger et al., 2014, p.2).

This "Socio-ecological System" is developed by Challenger and others (2014), under a holistic vision where the social system is incorporated into the ecological system and, then, is not limited only to the sum of its parts, but must be considered as a complete system where there are reciprocal and complex relationships between its components. In the last 20 years, the efficiency of this system has gained strength, not only in the field of research in which it is intended to understand the complexity of all its relationships, but also as a management guideline. (BALBI; GIUPPONI, 2010; BERKES; FOLKE, 1998; BRONDIZIO et al., 2009; COLLINS et al., 2007; GALÁN et al., 2013; HABERL et al., 2006; MAASS, 2012; OSTROM, 2007; WESTLEY et al., 2002, citado por CHALLENGER et al., 2014).

Ethnic communities that have traditionally used natural resources and services in a prudent manner are also involved in the provision of environmental services, taking into account that they allow the conservation of optimal natural conditions to support the sustainability of all. (UNIDADES DE CONSERVAÇÃO NO BRASIL, 2018). Considering the above, the hypothesis that social systems are not independent of ecological and environmental ones is validated. In fact, the subsistence of any social group depends on the environmental and ecosystem services that its environment provides. As stated by Rincón and others (2014), where they mention that this is an issue that has gained great importance in environmental discussions at a global level. 
Due to a close relationship that exists between native communities and the habitat that sustains them, some events have arisen around public policies that normalize the parameters and territories that benefit from contracting for environmental services. Then, Law 14,119 (2021) defines the criteria where the ecological importance of the area is observed, the priority of the services provided, the traditional communities and indigenous peoples that inhabit them.

The authors Zusman and Perla (2015, p. 229) consider that, "it is difficult to understand countries like Brazil, Argentina, Colombia or Mexico, without taking into account the geographical determinations of their history" and that the colonization process that lived in these countries expresses a territorial domain that is generated from the oppression of populations, the grabbing of spaces and the abuse of resources.

In the countries of colonial formation, the spatial dimension acquires special importance in the explanation of social processes and political life in particular $[\ldots]$. The colonial determination is inscribed in the patterns of organization of space, in the conformation of the territorial structure, in the modes of appropriation of nature and use of natural resources, in the fixing of the value of the land and in the forms of relationship between places. (MORAES, 1999, p. 43, our translation).

After the long process of colonization, political processes were developed that implied a change in the type of governmental regime, these generated alterations that sometimes are not so favorable in social organizations, relegating indigenous issues and rights to the background despite the establishment prior to laws that protect the conservation of its legacy, such as the Archaeological Heritage Protection Law of 1961.

With the restoration of civil governments, indigenous rights returned to the political agenda through public discussions and the demarcation of their lands; however, despite its importance, the indigenous presence in the country $[\ldots]$ has not always received due attention or recognition. (ENDERE; CALI; FUNARI, 2010, p. 275).

The International Labor Organization (ILO) (2014), since its creation in 1919, has paid main attention to the situation of indigenous and tribal peoples. Then, in June 1989, it adopted Convention No. 169, in whose revision process a large number of these peoples participated. This Convention is considered a key piece in the ILO's action in favor of social justice, with its two principles, namely: "the right of indigenous peoples to maintain and strengthen their own cultures, ways of life and institutions, and their right to participate effectively in the decisions that affect them". The Convention guarantees the right of these peoples to decide on their priorities in relation to their development process.

"The mandatory consultation of indigenous people in the event of water undertakings or mineral exploration on their lands" is the result of the Federal Constitution, in Chapter VIII, Articles 231 and 232, establishing political guidelines so that the link between the State and the indigenous communities of Brazil. (ENDERE; CALI; FUNARI, 2010, p. 283). In the same way, they are granted all the right and exclusive usufruct 
over the lands that they have traditionally occupied; therefore, the right of indigenous people to a specific land is independent of its formal recognition since it exists before the state itself was created, thus recognizing the original occupation of indigenous people in Brazilian territory. (POVOS INDÍGENAS NO BRASIL, 2018). On the other hand, and in accordance with the Act of Transitory Constitutional Provisions, in article 68, "the remnants of quilombo communities that are occupying their lands are recognized as definitive property and the State must issue the corresponding titles." (BRASIL, 1988, our translation).

Also, Decree 1775 of 1996 establishes the administrative process of demarcation of these lands, which in conclusion, currently, there are four different stages of the demarcation process: in identification, identified, declared and, homologated and reserved. (TERRAS INDÍGENAS NO BRASIL, 2018).

For their part, the quilombos have the National Institute for Colonization and Agrarian Reform (INCRA) which, through Decree 4887 of 2003, is granted the quality of competent authority for the titling of these lands. In this process, and as a first step, communities must define themselves by issuing a certificate issued by the Palmares Cultural Foundation (FCP), and thus start the process of titling their lands. (UNIDADES DE CONSERVAÇÃO NO BRASIL, 2018).

The International Union for the Conservation of Nature (IUCN) (2010) establishes that when public policies that regulate protected areas and indigenous territories harmonize with each other, it can be achieved that these two types of territories help to generate mutual protection by reducing pressure and implementing conservation objectives.

The recognition of the rights of ethnic communities, the protection of biodiversity and the formulation of public policies require joint work between the different institutions involved in the matter and also with the National Government. This aspect can be considered as the cornerstone that correctly directs the actions proposed by means of which it is intended to achieve the socio-cultural and environmental objectives.

For all the processes of social and institutional articulation, technical and scientific supports are needed that allow a real panorama or diagnosis of the ecological, environmental and socio-cultural conditions of the Brazilian territory. For this, it is essential that these processes are carried out synergistically with science and academia, since this not only provides a real diagnosis of the territories, but also allows the formulation of strategies that guarantee the protection and care of places and communities of interest, in a manner appropriate to the National Constitutional and responding to their economic development interests. Taking into account the importance of academia and research in all these processes of conservation and socio-environmental care, there are disciplines such as Environmental Engineering, Ecology, Anthropology and Sociology, among others, the above are named as some of the most prominent within of the information gathering, processing and evaluation processes.

Finally, the implementation of geographic information systems in the processes of identification and quantification of ecosystem services has been implemented to a greater extent in recent years, this allows spatial and territorial analyzes that serve to make esti- 
mates of reliable values and the efficient use of the resources. On the other hand, and as mentioned by Troy and Wilson (2006, cited by Haro and Taddei, 2010), the use of these geographic information systems requires greater knowledge about environmental services and the areas that provide them.

The importance of information systems or geographic analysis is increasingly evident, as stated by Haro and Taddei (2010), since they not only allow locating and delimiting any type of area of interest but also serve as a tool in the formulation or application of social, ecological and environmental evaluation or valuation methodologies. This type of software allows the integration of physical and biological characteristics in any territorial analysis, in addition to their respective social, economic and biophysical components. In this way, instruments that respond to compliance with the principles of sustainable development and the care of the different territories and the communities that inhabit them can be promoted.

This article, in which an assessment of environmental importance is carried out under the ecological and sociocultural axes in Brazil, is considered an example of the use of software, programs and / or methodologies that result in a highly useful input in the formulation of environmental public policies and decision-making at the national, regional and local levels.

The results of valuation of Brazilian sites presented in this article are the product of the overlap of the conservation units with ethnic territories, evaluating, for each one of them, attributes and recognitions that have been granted by different conservationist and naturalist organizations through the application of standardized criteria that, in some way, aim to guide the implementation of national conservation strategies, as has been done by BirdLife International ${ }^{1}$, among others.

Additionally, aspects of legal recognition for ethnic territories and geographic overlapping relationships of ecological and ethnographic territories were also evaluated. In this way, this work suggests a tool that can be used when establishing and prioritizing political and administrative actions regarding the protection of natural resources and conservation of socio-cultural heritage.

\section{Methodology}

The present research is of the applied type, taking into account that its object of study had a simple and complex extension, using non-experimental variables with measurement and analysis of qualitative and quantitative information; furthermore, it made use of documentary information sources, had a transversal temporal location and was based on techniques for obtaining data with low interference.

This work takes into account as a beginning the academic and research exercise

1 - Non-governmental organization with more than 100 partners around the world that works for the conservation of birds and global biodiversity. 
carried out by Acosta \& Piza (2017) and Cardozo \& Rodríguez (2017), in which the preliminary assessment of environmental importance was carried out, with respect to the ecological and sociocultural axes, of representative sites of Colombia, Ecuador, Peru and Venezuela. In its implementation in Brazil, it was divided into two (2) phases, which are described below:

\section{Phase I: Identification of sites to analyze}

In this phase, information from secondary sources was compiled and analyzed, mainly from official web pages of governmental institutions in Brazil and non-governmental institutions from different parts of the world that handle data and maps of: a) protected areas, b) sociocultural heritage, c) critical conservation areas and d) species conservation. Among the sources consulted are the following:

- Pages of the Socio-Environmental Institute (ISA), the MMA and the Critical Ecosystem Partnership Fund (CEPF);

- IUCN Red List of Conservation Status of Species;

- Listings from BirdLife International and Ramsar Convention;

- Mining titles from the continuous cartographic base of the Brazilian Institute of Geography and Statistics (IBGE), obtained from the Forest-GIS.com page;

- UNESCO listings;

- Lists of the National Institute of Historical and Artistic Heritage (IPHAN), georeferenced and validated by the registry and cadastre area of the National Archeology Center (CNA), according to the information obtained from the Forest-GIS.com page.

\section{Phase II: Selection and assessment of sites}

The assessments developed by Acosta \& Piza (2017) and Cardozo \& Rodríguez (2017) were focused on the exaltation of those places with great wealth in ecological and sociocultural aspects but that may be facing situations or conditions that threaten their conservation and sustainability. The method was based on a selection of places that had the presence of ecological and sociocultural attributes such as: endemism, hotspot, legal recognition of the area, declaration of cultural heritage or humanity, presence of archaeological sites, presence of ethnic groups, and of economic activity, considered by the authors as key aspects to determine conservation areas.

As a second measure, the selected territories were valued under the appreciation of ecological and sociocultural criteria considered of great relevance given their wealth, natural or human, their vulnerability and their conservation; this, by scoring with values of 1, 5 or 10, depending on whether the parameters of presence / absence, territorial influence and legal recognition were met. In this order of ideas, the highest score was given to the parameter that denotes more natural wealth, greater legal recognition and greater ecological vulnerability. The criteria taken into account are listed below. 
- Influence area (local, regional, national)

- Legal recognition of ecological areas (has / does not have)

- Ecosystem services (provides / does not provide)

- Anthropic pressure (high / medium / low)

- Conservation status of species (out of danger / vulnerable / endangered)

- Landscape quality (high / medium / low)

- Legal recognition of ethnic groups and archaeological sites (has / does not have)

- Seniority (greater or less than 30 years)

- Historical value (has / does not have).

- Symbolic value (has / does not have).

- Spiritual value (has / does not have).

To carry out its application in Brazil and taking into account these methodological parameters, the selection of sites was developed taking into account as the only criterion the geographical overlap, total or partial of protected areas represented by the conservation units with the presence of ethnic communities, or that there was a maximum distance of $1 \mathrm{~km}$ between them. The above, making use of "shapefiles" formats, in the ArcGIS Geographic Information System. In this way, the concept of protected areas as the primary territorial unit of ecological conservation is consolidated, and that of ethnic territories as natural guarantor units of said conservation, both types of territories becoming the starting point of the valuation.

Consequently, the need was generated to rethink methodological aspects that would allow a broader and more productive application of the methodology, in such a way that it takes into account the ecological, patrimonial and cultural diversity of Brazil. In this sense, the modifications listed below were implemented:

- Passing some selection criteria to the assessment stage, such as: biodiversity hotspots, declaration of cultural heritage and presence of archaeological sites.

- Elimination of criteria because they are considered closely related to others evaluated or because their recurring presence was taken for granted, reducing their sense of particularity at the time of rating; such is the case of endemism, which is closely related to the biodiversity hotspots criterion.

- Preservation of some parameters of the initial methodology, but with changes in its scoring criteria; such is the case of the area of influence, anthropic pressure and the conservation status of the species, moving from a qualitative to a quantitative assessment (percentage relationship or score for presence/ absence of attributes).

- Introduction of new valuation parameters, such as: being classified as a Biosphere Reserve, Ramsar sites, key biodiversity sites (KBA / IBA) and others that seek to qualify the close relationship that ethnic and protection territories may have with other ecological or socio-cultural entities, such as: 
integrated areas and the relationship between indigenous land and quilombos.

Next, the evaluation criteria for the ecological and sociocultural axes are defined and, in Table 1, their scores are presented.

Ecological Axis:

- Influence Area (AI): area of essential environmental importance to conserve biodiversity and culture, as well as its different ecosystem services. A percentage relationship was made between the area of each conservation unit within the corresponding biome and this value within the total area of Brazil, thus establishing three scoring ranges.

- Integrated Areas (AIN): refers to conservation units (UC) that overlap with other (s) or with ecological corridors (CE), which may manifest different characteristics, and the provision of particular goods and services. Therefore, the presence or absence of these within the evaluated conservation unit is a particularity that can denote an additional and particular ecological value.

- Anthropic Pressure (PA): direct or indirect human intervention on AI. This intervention can reduce the quality of life of communities, as well as the integrity of the environment and ecosystems. In this sense, extractive activities such as mining (MI), hydrocarbons (HC) and deforestation (DEF) were taken into account. Due to insufficient data or incomplete data, some criteria establish a score of zero.

- Species Conservation Status (ECE): the categories defined under the threat status of the IUCN Red List were taken into account, namely: critically endangered (CR), endangered (EN) and vulnerable (VU), in addition to the category near threatened (NT), for its acronym in English. The sum of the species found in these categories was carried out by federal states, making a percentage calculation on the total of species evaluated in that same region. In those cases where only one extinct species was found in the Wild (EW), it has the highest score.

- Ramsar Sites (RAM): they are designated by meeting the criteria for the identification of Wetlands of International Importance (RAMSAR). In this sense, the following were taken into account: total presence, if RAM covers the entire area of the UC; partial presence, if RAM covers less than half of the UC area; and, absence, if UC does not match RAM.

- Hotspot (HP): these are the richest terrestrial regions in biological terms, but they are threatened. The area must comply with at least 1,500 endemic plant species that have lost more than $70 \%$ of their primary native vegetation (CRITICAL ECOSYSTEM PARTNERSHIP FUND, 2018).

- Biosphere Reserve (RB): these are areas composed of terrestrial, marine and coastal ecosystems, where biological diversity is combined with cultural wealth. They also provide important ecosystem services such as provision, regulation, cultural and support (UNESCO, 2018). 
- IBA_KBA Sites (IBA_KBA): it is a global initiative (IUCN, BirdLife International, CI, among others) that focuses on the identification, documentation and conservation of sites classified as Key Biodiversity Areas (KBA) and Importance for the Birds Areas (IBA). In this sense, we have: total presence, if the declared KBA / IBA site covers the entire UC area; partial presence, if the declared KBA / IBA site covers less than half of the UC area; and, absence, if the UC does not coincide with the declared site KBA / IBA).

- UNESCO Natural Heritage (PN): those recognized for possessing "remarkable natural phenomena, representing some of the stages of Earth's history, displaying significant ecological and biological principles, or containing important natural environments." (UNESCO, 2019).

Sociocultural Axis:

- Recognition Status (REC): legal or administrative situation in which an indigenous land (TI) or quilombo (QUI) is found, according to the country's government guidelines; so that if there was a presence of TI in the UC in the states of: declaration, homologation or regulation, and / or presence of QUI with a degree, the lowest score, and the highest, were awarded to the TI or QUI that present absence of some kind of recognition.

- Relationship between TI and QUI (REL TI_QUI): it is the relationship that exists between the quantity and diversity of TI or QUI found within the UC.

- Historical Value $(\mathrm{VH})$ : it refers to those ethnic groups involved in the national history and that are considered or represent an essential component within the country, since they are part of the reconstruction of the historical memory of a community.

- Archaeological Site (SA): they are defined as those territories in which the presence of remains of some type of activity is registered, the formation of an SA is preceded by the adaptation, use and abandonment of a habitat by any type of community (CARRETÓN, 2016).

- Cultural Heritage (PC): it is defined as follows:

a) Monuments: architectural, sculpture or painting works, elements or structures of an archaeological nature, inscriptions, caves and groups of elements, which have an exceptional universal value from the point of view of history, art or science.

b) Sets: groups of buildings, isolated or reunited, whose architecture, unity and integration into the landscape give them an exceptional universal value from the point of view of history, art or science.

c) Places: works of man or joint works of man and nature, as well as areas, including archaeological sites, that have exceptional universal value from a historical, aesthetic, ethnological or anthropological point of view (UNESCO, 2018) 
Table 1 -Evaluation of criteria for the ecological and sociocultural axes

Criteria

\section{Assessment}

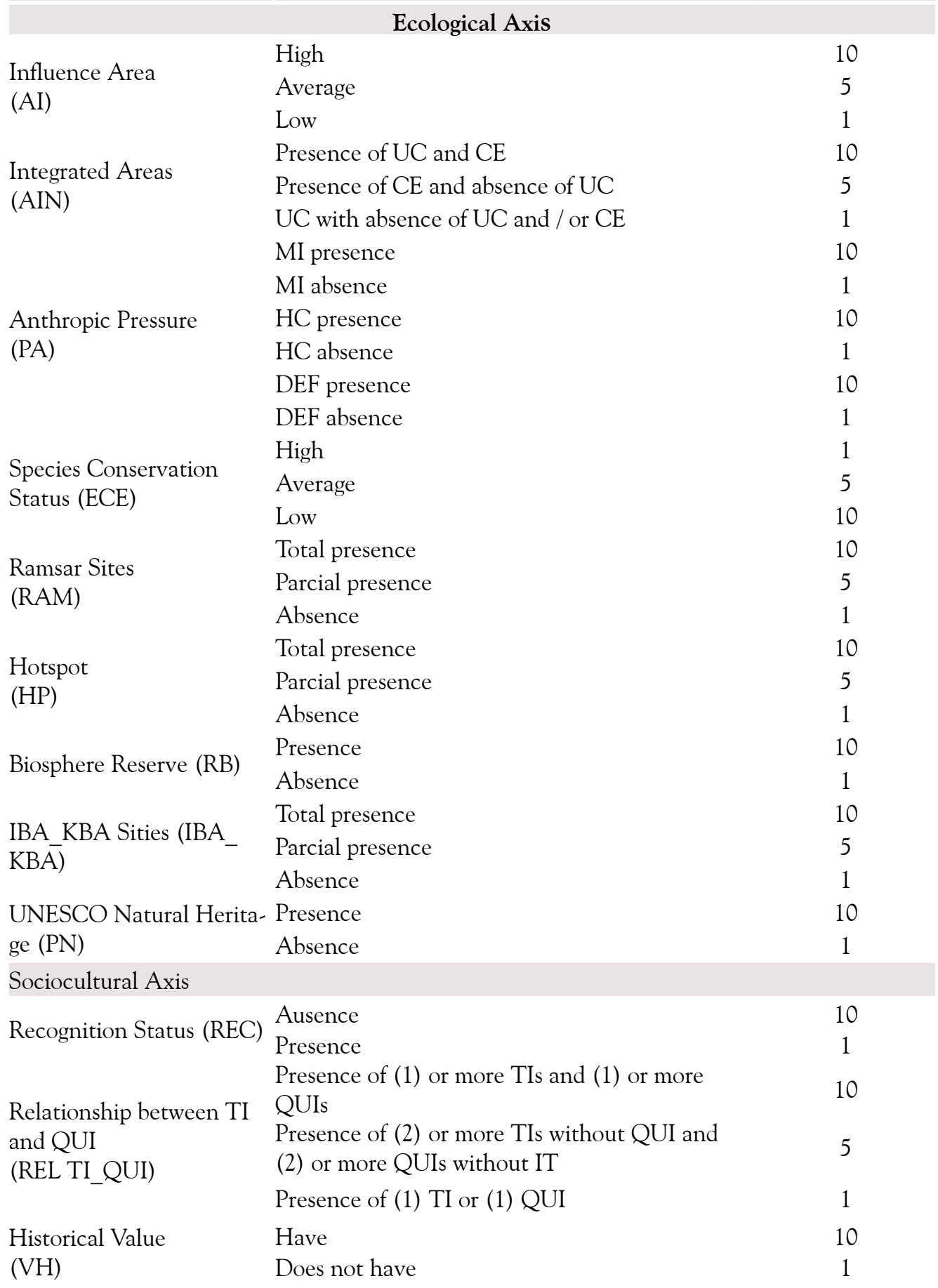




\section{Criteria}

Archaeological Site (SA)

Cultural Heritage

(PC)

\section{Assessment}

Presence

Absence

Presence

Absence
10

1

10

Source: Authors, 2021.

Considering the score of each parameter, the values of each thematic axis (ecological and sociocultural) were determined, by calculating the arithmetic average, as indicated in Equations 1 and 2.

Ecological Axis Value $=\left\{\frac{\left(A I+A I N+P A+E C E+H P+R B+\left(I B A_{-} K B A\right)+P N+R A M\right)}{9}\right\}$

$$
\text { Sociocultural Axis Value }=\left\{\frac{\left(S A+R E C+V H+\left(R E L T I_{-} Q U I\right)+P C\right)}{5}\right\}
$$

The final assessment also refers to an arithmetic average, calculated with Equation 3.

$$
\text { Final Value }=\left\{\frac{\text { Ecological Axis Value }+ \text { Sociocultural Axis Value }}{2}\right\}
$$

Finally, with "Equation 4" it was possible to define the valuation ranges, where the maximum value obtained in the weighting was taken, as a result of applying Equation 1, and subtracting the minimum value and then dividing between the number of categories, which for this case is three.

$$
\text { Rating Ranges }=\frac{\text { Maximum value }- \text { Minimum value }}{3}
$$

\section{Results}

\section{Phase I: Identification of sites to analyze}

Taking into account the information on the pages and documents consulted, I identify the existence of 1651 conservation units recognized and categorized under the 
Brazilian conservation unit system. Their distribution throughout the territory showed that the biomes with the highest number of these were Mata Atlântica, Amazonas and Cerrado; however, the Amazon biome, which occupies 49.3\% of the Brazilian territory, has units of greater area or extension, as well as the indigenous lands present.

Regarding the ethnic aspect, 600 indigenous lands were identified distributed in the following recognition phases with their percentage approximation: under study, $1.2 \%$; delimited, 5.7\%; declared, 12.3\%; approved, 2.7\%; and, regularized, $78.2 \%$. At addition, a list of 388 quilombo communities was found.

\section{Phase II: Selection and assessment of sites}

Considering the geographical overlap of conservation units with ethnic communities, and the distance between them, 249 sites were selected, whose distribution by biome is presented as follows: $51.0 \%$ in Amazonia, 35.3\% in Mata Atlântica, 7.2\% in Cerrado, $4.8 \%$ in Caatinga, $1.2 \%$ in Pantanal and $0.4 \%$ in Pampa. The foregoing is consistent with the distribution and total number of conservation units, as well as with that of ethnic communities throughout the country.

After assigning the scores to each criterion and assessing each area of environmental importance for the selected sites, making use of equations 1, 2 and 3, it was obtained as maximum and minimum values 7.6 and 1, respectively, and then apply Equation 4 and thus define 3 valuation ranges through which all the places valued according to their level of importance were classified, namely: high (14 sites, with values between 5.41 and 7.6), medium (91 sites, with values between 3.21 and 5.4) and low (144 sites, with values between 1 and 3.2).

Table 2 shows the results of the assessment for the category "High priority sites of environmental importance". 


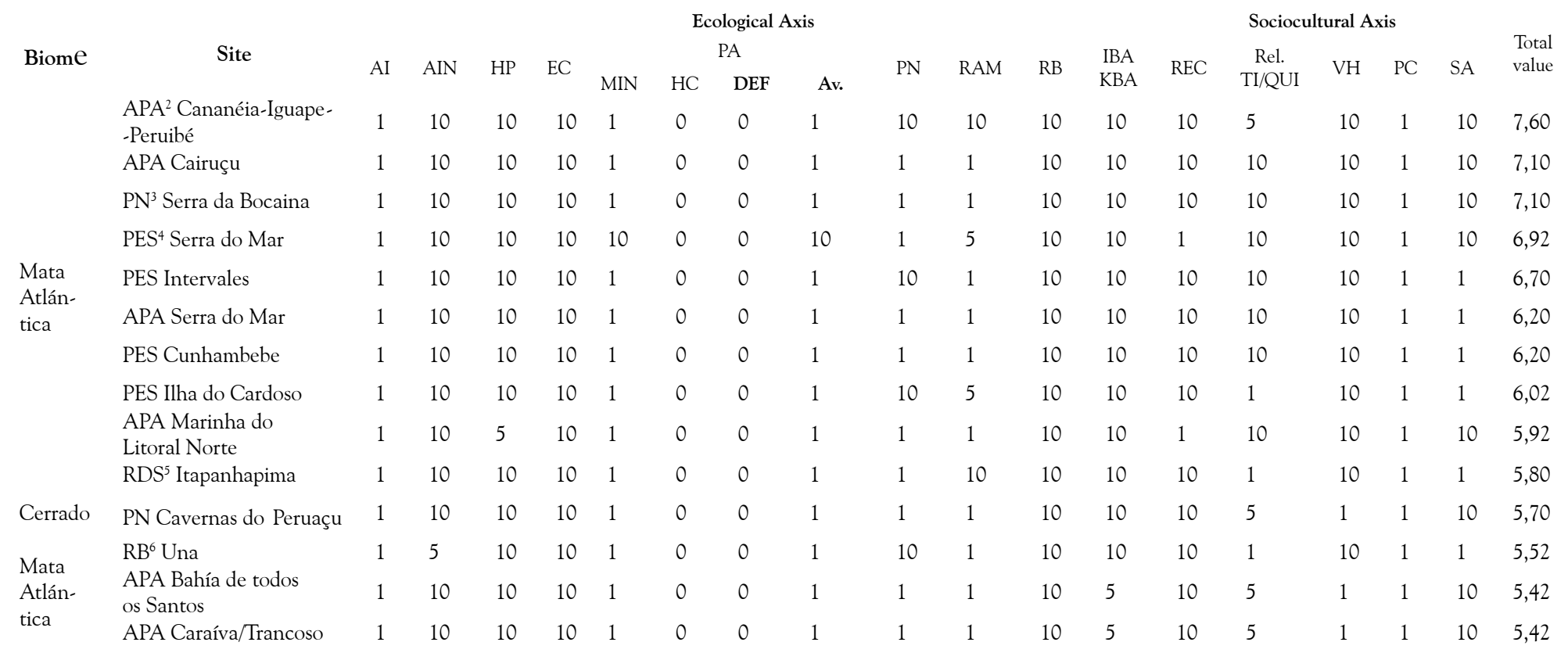

${ }^{2}$ Environmental Protection Area (APA, for its acronym in Portuguese)

${ }^{3}$ Nacional Park (PN, for its acronym in Portuguese)

${ }^{4}$ Statal Park (PES, for its acronym in Portuguese)

${ }^{5}$ Sustainable Development Reserve (RDS, for its acronym in Portuguese)

${ }^{6}$ Biological Reserve (RB, for its acronym in Portuguese)

Source: Authors, 2021. 
Finally, on Figure 1 you can see the location of the sites of environmental importance with high, medium and low priority in the Brazilian territory, also, on Figures 2 and 3 you can see the specific location of the sites of environmental importance with high priority, distributed in the Mata Atlântica and Cerrado biomes.

Figure 1 - Sites of environmental importance with high, medium and low priority

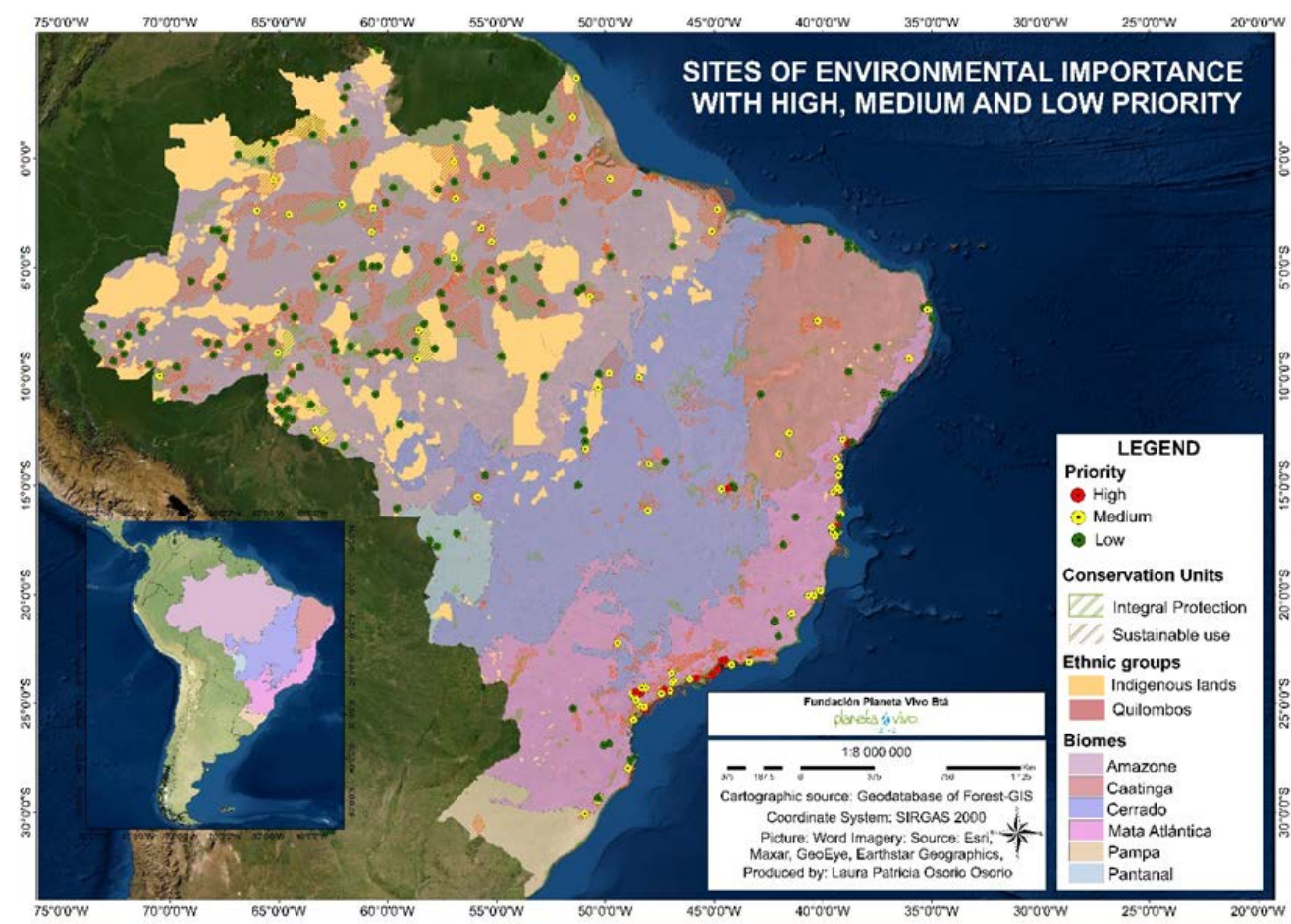

Source: Authors, 2021. 
Figure 2 - Sites of high priority environmental importance, Mata Atlantica (northern zone) and Cerrado biomes

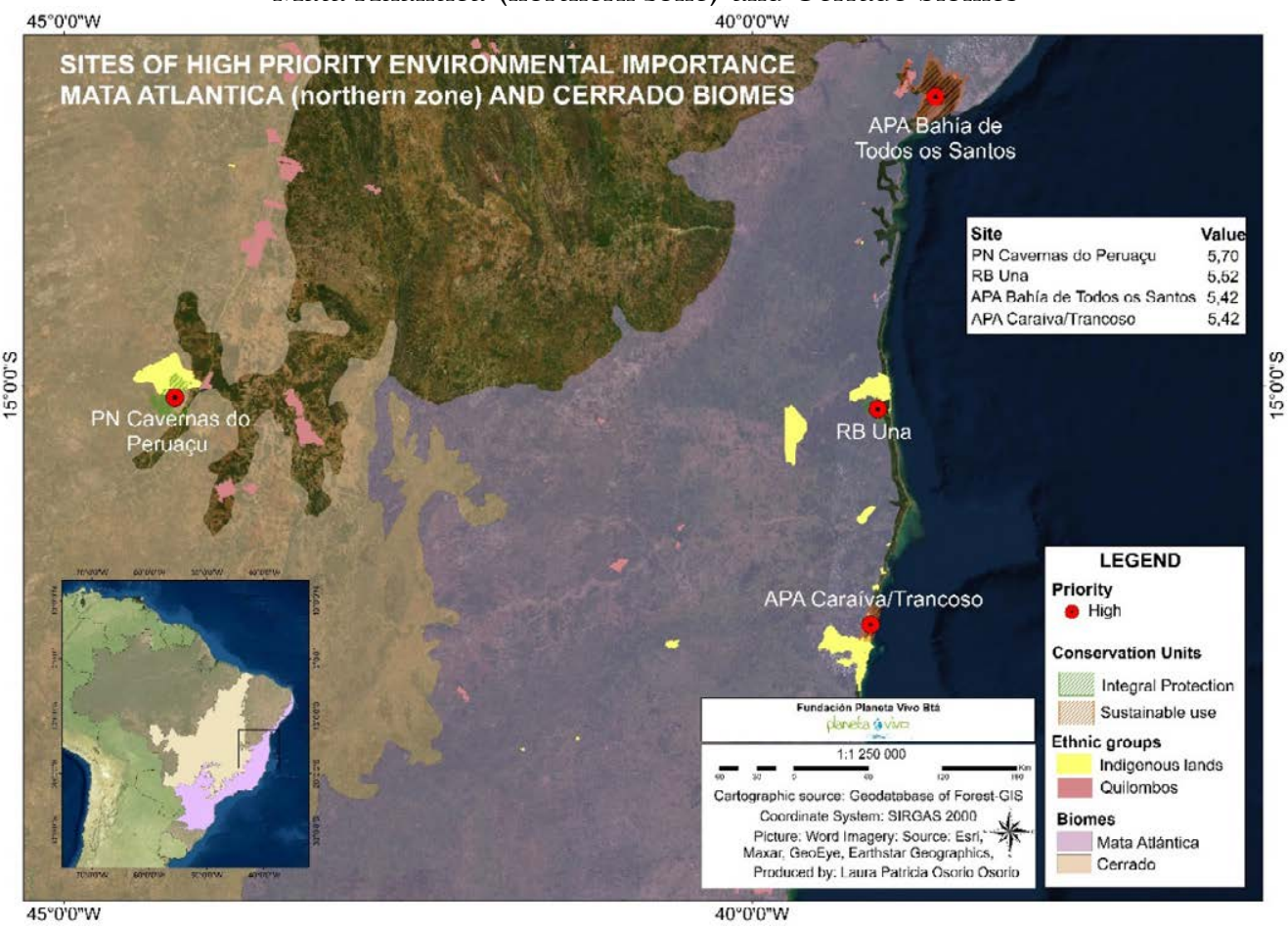

Source: Authors, 2021. 


\section{Figure 3 - Sites of high priority environmental importance, Mata Atlantica biome (southern zone)}

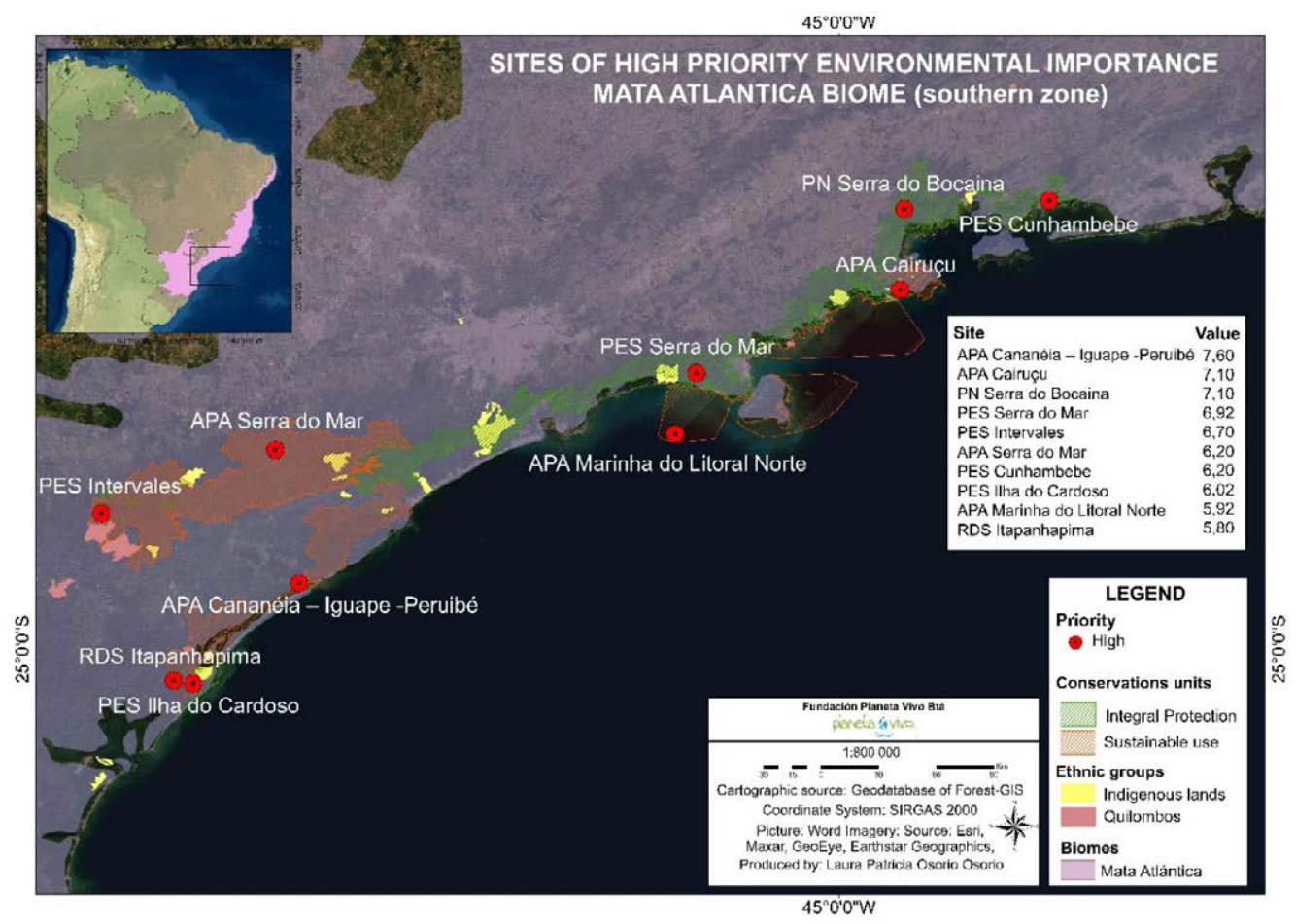

Source: Authors, 2021.

The results obtained shown that the places with the highest value are concentrated in the Atlantic Forest and specifically in the coastal zone. In this context, it is important to highlight that these are places that, in their entirety, are part of the areas declared "hotspots", "biosphere reserves" and "KBA / IBA", and also the conservation status of species is low. Also, and despite the fact that the area of influence did not obtain a high score for any of the places, it can be seen that all have the particularity of having areas integrated within the main conservation unit and / or an ecological corridor associated with them, which resulted in a higher score.

It became evident that the sociocultural axis was also an important element in the scoring of these places, since they are places where there are ethnic groups which constitute a very important historical value, due to the events that occurred in Brazil at the time of Portuguese colonization. In addition, these communities share a common space and, therefore, there is a diversity of different ancestral or cultural activities that identify the territory, and represent a characteristic cultural value. 


\section{Conclusions}

It was evidenced that the methodological tools should be dynamic, taking into account that they allow adaptation to the characteristics and particularities of the territories, so that they can offer a broader vision within a context that tends to be increasingly faithful to reality.

Considering the number of conservation units present in Brazil, the extension of its territory, the multiculturalism that characterizes it, the biodiversity and the present endemism, 1,651 environmental protection sites were identified. Subsequently, and thanks to the adjustments made in the methodology, it was possible to reduce this number to 249 valued sites. These places cover all the country's own biomes, however with a greater concentration in the Amazon and the Atlantic Forest.

It can be observed that the confluence of several criteria that affirm each other, contributed in a forceful way to the geographical concentration of the places with the highest qualifications since, despite its great extension, it is not a coincidence that Brazil presents, in a concentrated way, places of great biodiversity accompanied by a notable state of vulnerability and threat and which, in turn, have been sites where an important part of the development of history took place and continues to represent a vital territory for the culture conservation.

On the other hand, despite the fact that the vast majority of parameters subjected to qualification have recognition or appointment that, in itself, already suggests a nature of protection and conservation, it is noteworthy that it is not shown as a single tool to generate the necessary and sufficient changes; proof of this is that despite having at least one recognition attribute, threats to systems persist as well as their vulnerability.

Because jobs like this require the collection and processing of large amounts of information, most of which is owned by government entities, it is recommended that it be available to academia in order to make these assessment exercises possible. The foregoing, taking into account the difficulties presented by not counting, for each protection zone, with complete information on environmental damage and the pressure exerted by anthropic activities of deforestation, mining, hydrocarbon extraction, agro-industrial activities, tourism and recreation, among others.

Also, given the importance of geographic analysis software, such as ArcGIS, in environmental evaluation or assessment processes, it is recommended to periodically generate and update the data that can be processed in this type of tools and that contain information on location, reduction or expansion of areas of environmental and social importance, as well as anthropic activities. In this way, it will be possible to carry out analyzes that allow evidence of changes over time, in socio-environmental terms, throughout the brazilian territory.

This work shows a socio-environmental assessment and prioritization tool that provides technical support for decision-making, by the State of Brazil and its Institutions, in the field of public policy formulation aimed at the protection and conserva- 
tion of ecological resources and socio-cultural aspects of the country, contributing to its process of socio-environmental sustainability. Taking into account the above, it is recommended that the results be socialized and made available to civil society and government entities, in order to strengthen the social structure and promote citizen participation in the aforementioned decision-making process. The foregoing, considering that these public policies should serve as an instrument that assists economic models in terms of sustainability and conservation of socio-cultural heritage.

\section{References}

ACOSTA, Carlos Andrés; PIZA, Angie Carolina. Valoración preliminar ambiental de sitios más representativos de los territorios de Colombia y Venezuela, con respecto a los ejes ecológico, social y cultural. Trabajo para optar por el título de Ingeniería Ambiental. Universidad Distrital Francisco José de Caldas. Bogotá, 2017.

BRASIL. Ley n. 14.119, de 13 de enero de 2021. Instituye la Política Nacional de Pago por Servicios Ambientales; y modifica las Leyes 8.212, de 24 de julio de 1991, 8.629, de 25 de febrero de 1993, y 6.015, de 31 de diciembre de 1973, para adecuarlas a la nueva política. Diário Oficial da União. Brasilia, 14 ene. 2021, edición 9, sección 1.

BRASIL. Constitución Política de la República Federativa de Brasil, de 5 de octubre de 1988. Acto de Disposiciones Constitucionales Transitorias, Art. 68, n. 20. Diario Oficial de la República Federativa de Brasil, Brasilia, n. 191-A, p. 130, 5 oct.1988.

CARDOZO, Manuel Alberto; RODRÍGUEZ, Jeffer Anceno. Valoración preliminar de importancia ambiental de sitios representativos en el territorio ecuatoriano y peruano, con respecto a los ejes ecológico, social y cultural, 2017. Trabajo para optar por el título de Ingeniería Ambiental. Universidad Distrital Francisco José de Caldas. Bogotá, 2017.

CARRETÓN, Adrián. El proceso de formación de los yacimientos arqueológicos. Patrimonio inteligente, 2016. Disponible en: http://www.patrimoniointeligente.com/proceso-formacion-los-yacimientos-arqueologicos/. Acceso en: 15 de Jun. de 2018

CEPF - CRITICAL ECOSYSTEM PARTNERSHIP FUND. Los hotspot El fondo de alianzas para ecosistemas críticos. Disponible: https://www.patrimonionatural.org.co/redes-y-plataformas/ hotspot/. Acceso en: 24 Abr. 2018.

CHALLENGER, Antony. et al. La aplicación del concepto del sistema socioecológico: alcances, posibilidades y limitaciones en la gestión ambiental de México. Investigación Ambiental, México, vol. 6 no. 2, p.2, 2014. Disponible en: https://www.academia.edu/11856224/ La_aplicaci\%C3\%B3n_del_concepto_del_sistema_socio_ecol\%C3\%B3gico_alcances_ posibilidades_y_limitaciones_en_la_gesti\% $\mathrm{C} 3 \% \mathrm{~B} 3 \mathrm{n}_{-}$ambiental_de_M\%C3\%A9 xico_Applying_the_concept_of_the_Socio_ecological_system_scope_possibilities_and_limitations_in_ the_environmental_management_of_Mexico. Acceso en: 15 Jul. 2018 
DA LUZ, Fabian Cristina et al. O tratamento dispensado aos conflictos que envolvem direito ao meio ambiente e direito à moradia: Análise dos trabalhos apresentados no II seminário nacional sobre áreas de preservação permanente em meio urbano. V. 15, n. 1, p. 3, 2003. Disponible en: http://anais.anpur.org.br/index.php/anaisenanpur/article/view/267. Acceso en: 14 Jun. 2018.

DOS SANTOS, Theotonio. et al. La economía mundial y America Latina. Tendencias, problemas y desafíos. Consejo Latinoamericano de Ciencias Sociales. Disponible en: http://biblioteca. clacso.edu.ar/clacso/gt/20101013121047/estay.pdf. Acceso en: 11 abr. 2020.

ENDERE, María; CALI, Plácido; FUNARI, Pedro Paulo. Arqueología y comunidades indígenas. Un estudio comparativo de la legislación de Argentina y Brasil. In: GNECCO, Cristóbal (comp); AYALA, Patricia (comp). Pueblos indígenas y arqueología en América Latina. Editorial Universidad de los Andes, 2010. p. 273-299.

HARO, Angelina Alma; TADDEI, Cristina. Valoración ambiental: aportaciones, alcances y limitaciones. Revista latinoameticana de Economía, vol 41, num 160, enero/marzo, 2010.

LIMA, Gustavo Ferreira da Costa. A institucionalização das políticas e da gestão ambientalno Brasil: avanços, obstáculos e contradições. Desenvolvimento e Meio Ambiente. n. 23, p. 4, 2011. Disponible en: https://revistas.ufpr.br/made/article/view/20948/14461. Acceso en: 21 Jun. 2018.

MMA - MINISTÉRIO DO MEIO AMBIENTE. Biodiversidade Brasileira. Disponible en: http://www.mma.gov.br/biodiversidade/biodiversidade-brasileira. Acceso en: 05 Jun. 2018.

MMA - MINISTÉRIO DO MEIO AMBIENTE. Biomas. Disponible en: https://www.mma.gov. br/biomas.html. Acceso en: 07 Jun. 2020.

MORAES, Carlos. Some notes on territorial formation and environmental policies in Brazil. In: Congresso Brasil - Portugal Ano 2000 (Lisboa, 16-18/6/1999), p. 43. Disponible en: http://www. laget.eco.br/pdf/07_4_moraes.pdf. Acceso en: 25 Abr. 2018.

OIT - ORGANIZACIÓN INTERNACIONAL DEL TRABAJO. Convenio Número 169 de la OIT sobre pueblos indígenas y tribales en países independientes. Declaración de las Naciones Unidas sobre los Derechos de los Pueblos Indígenas. Lima: OIT/Oficina Regional para América Latina y el Caribe, 2014.

PACHA, María José. Valoración de los servicios ecosistémicos como herramienta para la toma de decisiones: Bases conceptuales y lecciones aprendidas en la Amazonía. Brasília, Iniciativa Amazonia Viva, 2014.

PIB - POVOS INDÍGENAS NO BRASIL. Direitos constitucionais dos índios. Disponible en: https://pib.socioambiental.org/pt/P\%C3\%A1gina_principal. Acceso en: 16 Mar. 2018

PNUD - PROGRAMA DE LAS NACIONES UNIDAS PARA EL DESARROLLO. América Latina y el Caribe: "Una superpotencia de la biodiversidad, 2013. Disponible en: https:// www.undp.org/content/undp/es/home/presscenter/pressreleases/2010/12/02/amrica-latina-y-el-caribe-superpotencias-de-biodiversidad.html. Acceso en: 02 Agos. 2020. 
RINCÓN, Alexander. et al. Valoración integral de la biodiversidad y los servicios ecosistémicos: Aspectos conceptuales y metodológicos. Instituto de Investigación de Recursos Biológicos Alexander von Humboldt (IAvH), Bogotá, p. 19, 2014. Disponible en: file://C:/Users/Soporte/ Downloads/VIBSE_2014_1.pdf. Acceso en: 23 Abr. 2018.

STEINBERGER, Marilia. Política ambiental: intervenção do Estado no uso da naturaleza e do território. Brasilia: LER Editora Ltda, 2013.

TERRAS INDÍGENAS NO BRASIL. Disponible en: https://terrasindigenas.org.br/. Acceso en: 15 Mar. 2018

UICN - UNIÓN INTERNACIONAL PARA LA CONSERVACIÓN DE LA NATURALEZA. Superposición de territorios indígenas y áreas protegidas en América del sur, 2010.

UC - UNIDADES DE CONSERVAÇÃO NO BRASIL. ¿Qué son los servicios ambientales? Disponible en: https:/uc.socioambiental.org/es/servi\%C3\%A7os-ambientais/\%C2\%BFqu\%C3\%A9. -son-servicios-ambientales. Acceso en: 4 de Mar. 2018.

UC - UNIDADES DE CONSERVAÇÃO NO BRASIL. Unidades de conservación. Disponible en: https://uc.socioambiental.org/. Acceso en: 21 Mar. 2018

UNESCO. Reservas de la Biosfera. Disponible en: http://www.unesco.org/new/es/office-in-montevideo/ciencias-naturales/ecological-sciences/biosphere-reserves. Acceso en: 12 May. 2018.

UNESCO. Patrimonio. Disponible en: https:/es.unesco.org/creativity/sites/creativity/files/digital-library/cdis/Patrimonio.pdf. Acceso en: 02 Jun. 2018.

ZAMBRANO, Silvia Patricia; CÉSPEDES, Lianet; SERRANO, Javier. Políticas públicas en defensa de la naturaleza, casuística y penalidad en Ecuador. Revista Universidad y Sociedad, República del Ecuador, vol. 10 no. 2, p. 2, 2018. Disponible en: http://scielo.sld.cu/scielo. php?script=sci_arttext\&pid=S2218-36202018000200234. Acceso en: 13 may. 2018.

ZUSMAN, Perla. Antonio Carlos Robert Moraes (1954-2015): Movilidad y formación colonial. Revista Transporte y Territorio, Argentina, vol 13, p. 229. Disponible en: http://revistascientificas.filo.uba.ar/index.php/rtt/article/view/1885/1771. Acceso en: 03 Jun. 2018. 
Martha Isabel Mejía De Alba

$\checkmark$ mimejiaa@udistrital.edu.co

ORCiD: https://orcid.org/0000000194389026

\section{Oscar Javier Obando Rodríguez}

$\square$ fundacion.planetavivo@gmail.com

ORCiD: https://orcid.org/0000000158901723

\section{Laura Patricia Osorio OsorioOsorio}

$\checkmark$ lauraosorio144@outlook.com

ORCiD: https://orcid.org/0000000279234920

Laura Patricia Osorio OsorioOsorio

\section{Ivonne Dayana Vargas Pinilla}

\idvp81@gmail.com

ORCiD: https://orcid.org/0000000204027660
Submitted on: 04/09/2019

Accepted on:18/07/2021

2021;24e:02091

How to cite: MEJIA, M. I.; OBANDO, O. J.; OSORIO, L. P.; VARGAS, I. D. Preliminary valuation of environmental importance of brazilian places, with regards to ecological and sociocultural axes. Ambiente \& Sociedade. São Paulo, v. 24, p. 1-23, 2021. 


\title{
Avaliação preliminar da importância ambiental de sítios brasileiros, com respeito aos eixos ecológico e sociocultural
}

\author{
Martha Isabel Mejía De Alba \\ Oscar Javier Obando Rodríguez \\ Laura Patricia Osorio \\ Ivonne Dayana Vargas Pinilla
}

São Paulo. Vol. 24, 2021

Artigo Original
Resumo: O objetivo deste artigo é estabelecer prioridades para os sítios de importância ambiental no Brasil de acordo com suas necessidades de proteção e conservação. Para isso, foi aplicada uma metodologia na qual os sítios que apresentaram sobreposição geográfica ou proximidade entre áreas protegidas e comunidades étnicas foram selecionados para ser avaliados de acordo com critérios que definem sua importância ecológica e sociocultural, tais como: área de influência, áreas integradas, pressão antrópica, estado de conservação das espécies, sítios Ramsar, hotspot, reserva da biosfera, sítios IBA e KBA, patrimônio natural, status de reconhecimento e relação entre terras indígenas e quilombolas, valor histórico, sítios arqueológicos e patrimônio cultural. Como resultado, foram identificados 1651 sítios, sendo selecionados e avaliados 249, obtendo-se 14 com alta prioridade, 91 com média e 144 baixa. Com os resultados, espera-se gerar suporte técnico útil na geração de políticas públicas voltadas à sua proteção e conservação.

Palavras-chave: Avaliação ecológica e sociocultural; sítios de importância ambiental; vulnerabilidade ambiental no Brasil; política ambiental brasileira.

Como citar: MEJÍA, M. I.; OBANDO, O. J.; OSORIO, L. P.; VARGAS, I. D. Avaliação preliminar da importância ambiental de sítios brasileiros, com respeito aos eixos ecológico e sociocultural. Ambiente $\mathbb{\&}$ Sociedade. São Paulo, v. 24, p. 1-23, 2021. 


\title{
Valoración preliminar de importancia ambiental de sitios brasileños, respecto a los ejes ecológico y sociocultural
}

\author{
Martha Isabel Mejía De Alba \\ Oscar Javier Obando Rodríguez \\ Laura Patricia Osorio \\ Ivonne Dayana Vargas Pinilla
}

São Paulo. Vol. 24, 2021

Resumen: El presente artículo tiene como fin priorizar sitios de impor-

Artículo original tancia ambiental de Brasil, según su necesidad de protección o conservación. Para ello, se aplicó una metodología en la cual se seleccionaron los sitios que presentaron superposición geográfica o cercanía entre áreas protegidas y comunidades étnicas para ser evaluados teniendo en cuenta criterios que definen su importancia ecológica y sociocultural, tales como: área de Influencia, áreas integradas, presión antrópica, estado de conservación de especies, sitios Ramsar, hotspot, reserva de la biosfera, sitios IBA y KBA, patrimonio natural, estado de reconocimiento y relación entre tierras indígenas y quilombos, valor histórico, sitios arqueológicos y patrimonio cultural. Como resultado, se identificaron 1651 sitios, se seleccionaron y valoraron 249, obteniéndose 14 con prioridad alta, 91 media y 144 baja. Con esta información, se busca generar soporte técnico que sirva de insumo para la generación de políticas públicas tendientes a su protección y conservación.

Palabras-clave: Valoración ecológica y sociocultural; sitios de importancia ambiental; vulnerabilidad ambiental en Brasil; política ambiental brasileña.

Como citar: MEJÍA, M. I.; OBANDO, O. J.; OSORIO, L. P; VARGAS, I. D. Valoración preliminar de importancia ambiental de sitios brasileños, respecto a los ejes ecológico y sociocultural. Ambiente $\mathbb{\&}$ Sociedade. São Paulo, v. 24, p. 1-24, 2021.

DOI: http://dx.doi.org/10.1590/1809-4422asoc20200209r1vu2021L5AO 